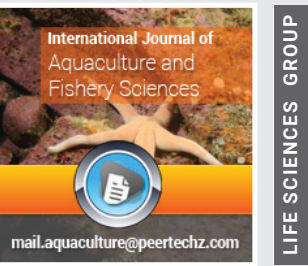

\section{Incorporation of Water}

Hyacinth, Eichhornia

crassipes Meal in Aqua-feed

and its Efficacy on Growth

Performance of roho labeo,

\section{Labeo rohita (Hamilton, 1822)}

\section{Reared in Cagev}

\section{Md. Al-Amin Sarker*, Kamrun Nahar, Hasna Banu and Turjaun Nesa}

Laboratory of Fish Nutrition, Department of Fisheries, University of Rajshahi, Rajshahi-6205, Bangladesh
Received: 27 November, 2019

Accepted: 27 May, 2020

Published: 28 May, 2020

*Corresponding author: Dr. Md. Al-Amin Sarker, Associate professor, Department of Fisheries, Faculty of Agriculture, The University of Rajshahi, Bangladesh, Tel: +88-0721-711117; FAX: +88-0721-750064;

E-mail:maa_sarker@yahoo.com

Keywords: Heart model; Synchronization; Arrhythmia; Ablations

https://www.peertechz.com

Check for updates

\begin{abstract}
The major challenge of fish production is to develop high quality low cost fish feed which indicates the importance of low cost aquaculture technology. This study was conducted to Incorporation of water hyacinth, Eichhornia crassipes meal in aqua-feed and its efficacy on growth and nutritional aspects of roho labeo, Labeo rohita (Hamilton, 1822) reared in cage during March to May, 2018. Feed formulation was performed with water hyacinth considering the nutritional balance of the feed. roho labeo were fed with control $\mathrm{T}_{1}$ feed ( $0 \%$ water hyacinth based WH 0 feed), $15 \%$ water hyacinth meal based feed $\mathrm{T}_{2}$ feed and $25 \%$ water hyacinth meal enriched feed $\mathrm{T}_{3}$ feed at the feeding level of $4 \%$ body weight for 12 weeks (twelve weeks) in experimental cages (each treatment with 3 replications) at Isamoti river, Santhia, Pabna, Bangladesh. The food conversion ratio (FCR) value was significantly lower in fish group fed with $T_{1}$ feed $(3.0 \pm 0.01)$ and $T_{2}$ feed (3.0 \pm 0.03$)$ than $T_{3}$ feed (3.5 \pm 0.04$)$. The average specific growth rates $(S G R)$ was $(1.11 \pm 0.00),(1.11 \pm 0.01)$ and $(0.95 \pm 0.01)\left(\%, b^{-1}\right.$, body weight per day) in treatment $T_{1}, T_{2}$ and $T_{3}$ respectively. The $S G R$ was significantly $(P<0.05)$ higher in fish group fed with $\mathrm{T}_{1}$ feed $(1.11 \pm 0.00)$ and $\mathrm{T}_{2}$ feed $(1.11 \pm 0.01)$ than $\mathrm{T}_{3}$ feed $(0.95 \pm 0.01)\left(\%, \mathrm{bwd} \mathrm{d}^{-1}\right)$. The production $(\mathrm{kg} / \mathrm{cage} / \mathrm{cycle})$ of $L$ abeo rohita was $(40.41 \pm .19)$ $\mathrm{T}_{1},(40.49 \pm .21) \mathrm{T}_{2},(35.93 \pm .07) \mathrm{T}_{3}$ respectively. The production did not differ significantly between $\mathrm{T}_{1}$ and $\mathrm{T}_{2}$. Significantly higher cost benefit analysis (CBR) was found with $\mathrm{T}_{2}(0.68 \pm .02)$ and lower was found with $\mathrm{T}_{1}(0.61 \pm .01)$ and $\mathrm{T}_{3}(0.57 \pm .01)$. The cost of feed production decreases as the incorporation levels of water hyacinth increases.
\end{abstract}

\section{Introduction}

Bangladesh is an agro-based riverine country and is situated in the northern part of the south Asian sub-continent, has an area of $1,47,570$ sq.km. The country is blessed with vast inland water resources which offer great scope and potential for augmenting fish production by adopting culture based fisheries techniques. Bangladesh has a wide variety of fish species including 260 for freshwater and 475 for marine water [1]. Fish is the cheapest source of protein for human nutrition in the country, still with a gap in a production and supply. Hence, accelerating the development of aquaculture industry is important to fulfill the protein demand for increasing world's population. Fish and fisheries products provide about $60 \%$ of the country's animal protein [1]. The development of aquaculture industry is important to fulfill the protein demand for increasing world's population. Fish and fisheries item plays an important role to fulfill the demand of fish consumption [1].

A major determinant of successful growth of aquaculture 
depends on aqua feed. But, the uncertain availability and high cost of feed are important constrains for the development of aquaculture in Bangladesh. Therefore, the development of quality and low cost fish feed is crucial. The expansion of aquaculture correlated to increase in feed production and subsequently an increasing demand for fish meal. But according to FAO statistics, global fish meal production has remained fairly static. Also, reasons for current interest in its replacement irregular availability, variable quality, perceived contribution to deterioration of fishes, potential for adulteration, contamination with hydrocarbons and biological pathogens and increasing costs. For several years, there has been continuation interest in identifying and developing ingredients as alternatives to fish meal for use with in aquatic feed $[2,3]$. Among the ingredients that are been investigated as alternatives to fish meal, products derived from soybeans are some of the most promising work was reported [4-7].

Some of other indigenous available ingredients used throughout the country Bangladesh like mustard oil cake, coconut bran, potato, water hyacinth and other locally potential raw materials. Thus, the optimum protein requirement is the first nutritional parameter to be determined for formulated feed production for a newly established cultured fish species according to Kim and Lee (2009) [8]. Also improvements in growth, feed utilization efficiency and nutrient retention in fish fed such adequate lipid feed reported by Sargent et al., (2002) advantage of the fish farmer by giving a shorter grow-out period [9]. Studies have been conducted on the use of water hyacinth as feed for different fish species including Indian major carps $[10,11]$. A potential incorporation of water hyacinth meal in the diets for the fingerlings of the roho labeo [12], in common carp [13,14] and in mirror carp [15] found a good result. However, information on the use of processed leaf meals of water hyacinth in aqua feeds are scanty [16]. The roho labeo is primarily a herbivorous to omnivorous species and prefers to feed on plant materials [17]. Considering the above circumstance the present study was performed to Incorporate of water hyacinth, Eichhornia crassipes meal in aqua-feed and its efficacy on growth performance of roho labeo, Labeo rohita (Hamilton, 1822) reared in cage.

\section{Materials and methods}

\section{Location and duration}

Experimental studies were carried out under the Department of Fisheries, University of Rajshahi, Bangladesh. The rearing site was at Isamoti River, Santhia, Pabna. The effects of feeding water hyacinths meal on growth and production of roho labeo was evaluated for a period of 12 weeks during March to May, 2018 under cage culture.

\section{Experimental feed}

The experimental feed were formulated by the incorporation of water hyacinth at the level of $0 \%$ (control diet, WHo), $15 \%$ (WH15 diet) and 25\% (WH25 diet) (Table 1).An outer station was conducted with three treatments and three replications. The ingredients were well mixed and pelleted using a laboratory pellet machine. The pellet was dried using sundry and stored at cool place until use.
Table 1: Experimental feeds.

\begin{tabular}{|c|c|c|c|}
\hline Ingredients(g) & WH 0 & WH 15 & WH 25 \\
\hline Fish meal & 25 & 25 & 25 \\
\hline Mastared oil cake & 25 & 25 & 25 \\
\hline Maize & 10 & 10 & 10 \\
\hline Rice bran & 33 & 18 & 08 \\
\hline Eichhornia meal & 0 & 15 & 25 \\
\hline Soya bean oil & 5 & 5 & 5 \\
\hline Vitamin pre-mixture & 1.5 & 1.5 & 1.5 \\
\hline Choline chloride & 0.5 & 0.5 & 0.5 \\
\hline Total & 100 & 100 & 100 \\
\hline
\end{tabular}

\section{Making of cage}

The cages were constructed each with size of 6 meter long, 3 meter wide and 2 meter depth. All the Cages have been made by angle metal iron and special nylon net with $25 \mathrm{~mm}$ mash size. The sizes of the cage will $10 \mathrm{~m}^{3}$. The floating cages were fixed by bamboo and plastic dram. The cage will be set in fixed place on floating in River. The cage net was collected from Chandpur sadar, Bangladesh.

\section{Collection of fish}

The roho labeo, Labeo rohita (Ham. 1822) was selected for study around $200 \mathrm{~g}$ purchased from Parila, Rajshahi, Bangladesh. The roho labeo seed was collected from Padma river of Bangladesh part. The fish was carried out with the road transport by open transport system.

\section{Stocking}

All the fishes were acclimatized in a cage for three days with aeration system. In the acclimation time all the fishes fed commercial fish feed. The fishes were randomly released into different replicates of three treatments. Fish were stocked early in the morning. Stocking density was $2 \mathrm{fish} / \mathrm{m}^{3}$.

\section{Feeding}

According to the first size and weight a required amount of feed were given two times in a day into experimental cages. The feeds were supplied twice daily, in the morning (at 9.30am) and in the afternoon at $(4.30 \mathrm{pm})$ in cages at the rate of $4 \%$ of the body weight.

\section{Experimental conditions and feeding trail}

The fish at average body weight $200 \mathrm{~g}$ randomly distributed in each of the 9 cages with three replications. The rearing experiment was running for 12 weeks. The water quality parameters monitored every $4^{\text {th }}$ week. During the experimental period, fish was weighed after 4 weeks and the supplied diet pellet size was adjusted as fish.

\section{Water quality monitoring}

The physical parameters and chemical parameters were monitored. The water quality parameters viz. water temperature, hydrogen ion concentration $(\mathrm{pH})$, dissolved 
oxygen (DO) and free carbon dioxide $\left(\mathrm{CO}_{2}\right)$ were studied fortnightly between 10 am to 11 am for the present study.

\section{(i) Physical parameters}

\section{Water temperature}

Water temperature was measured using a Celsius thermometer. Similar process was followed three times and finally average value was recorded. The temperature was expressed as ${ }^{\circ} \mathrm{C}$.

\section{(ii) Chemical parameters}

\section{Dissolved Oxygen}

The dissolved oxygen concentration of water was determined by the aid of a water quality test kit (HACH kit FF2, USA). Alkaline Iodide-Azide powder pillows, Manganous sulfate powder pillows, Sodium thiosulfate titration cartridge $(0.2000 \mathrm{~N})$, Starch indicator solution and Sulfamic acid powder pillows were used for determination of dissolved oxygen. The concentration of dissolved oxygen thus estimated was expressed in milligram per litter $(\mathrm{mg} / \mathrm{l})$ of water.

\section{Free carbon dioxide $\left(\mathrm{CO}_{2}\right)$}

Free carbon dioxide was determined through digital titration by the help of a HACH kit (FF-2, USA). Phenolphthalein powder pillows and Sodium hydroxide titration cartridge $(0.3636 \mathrm{~N})$ were used for determination of free carbon dioxide. It was also expressed as $\mathrm{mg} / \mathrm{l}$ of water.

\section{Hydrogen Ion concentration $(\mathrm{pH})$}

The water $\mathrm{pH}$ of cage water was measured by using a $\mathrm{pH}$ indicator paper (Lojak). A small portion of this paper was rinsed into the water and after a few minutechanges in colour was matched with the reference colour of the discranging from $1-14$

\section{Sampling}

The fishes were sampled three times. The caged fishes were caught by scoop net from the cages. The body weights of fishes were recorded.

\section{Analysis of growth performance of fish}

\section{Final weight}

It was taken at the time of harvest and was express as (g).

Final weight $(\mathrm{g})=$ Weight of fish at harvest

\section{The mean weight gain}

The mean weight gain is calculated as-

Mean weight gain $=$ Mean final weight gain - Mean initial weight gain

\section{Specific Growth Rate (SGR)}

SGR (\%) was calculated by deducting the average initial weight from the average final weight.

SGR (\%) $=$ Ln $\{$ (Final weight $)-$ LN (Initial weight) /Culture period (day)\} X 100

Food conversion ratio (FCR)

Food conversion ratio (FCR) was also calculated to evaluate the feeding efficiency of fishes under different treatment as follows:

$$
\text { FCR }=\frac{\text { Food fed (dry weight })}{\text { Live weight gain }}
$$

\section{Production of fishes}

Production was calculated based on average final weight of the harvested fishes. The formula is as follows: Production= No. of fish harvested $\times$ final weight of fish. A simple economic analysis was done to estimate the economic return in each treatment. Data of both fixed and variable cost were recorded to determine the total cost $(\mathrm{Tk} / \mathrm{kg})$. Total returns were determined from the market price of fish and expressed as $\mathrm{Tk} / \mathrm{kg}$. Net benefit was calculated by deducing the total return from total cost and was expressed as $\mathrm{Tk} / \mathrm{kg}$. CBR was calculated as follows:

$$
\mathrm{CBR}=\frac{\text { net benefit }}{\text { total cost }}
$$

\section{Statistical analyses}

For the statistical analysis of collected data, one way analysis of variance was performed using computer software SPSS (Statistical Package for Social Science, Version 16.0). Significance was assigned at the $\mathrm{P}<0.05$ level. The mean values were also compared to see the significant difference from the DMRT (Duncan Multiple Range Test).

\section{Results and discussion}

\section{Mean variation in the water quality parameters}

A number of water quality parameters such as, water temperature, $\mathrm{pH}$, dissolved oxygen, ammonia, and free $\mathrm{CO}_{2}$ were measured fortnightly during the study period. The variation in the mean values of different water quality parameters under different treatments by total of all weeks are presented in Table 2 and Figures 1-4.

\section{Water temperature $\left({ }^{\circ} \mathrm{C}\right)$}

Temperature is one of the most important water quality parameter that influences the growth, food intake, reproduction and other biological activities of aquatic organisms. During the study period the highest temperature $\left(29.17 \pm 0.09^{\circ} \mathrm{C}\right)$ was recorded with the treatment $\mathrm{WH} 25\left(\mathrm{~T}_{3}\right)$ at $12^{\text {th }}$ week and the lowest value $\left(25.23 \pm 0.19^{\circ} \mathrm{C}\right)$ was recorded at $4^{\text {th }}$ week with the treatment WH $15\left(\mathrm{~T}_{2}\right)$.No significant differences $(\mathrm{P}<0.05)$ were found among the treatments for the mean values of water temperature. The present findings also agreed with Bhuiyan et al., (2002) who found that water temperature ranged from 27.95 
to $31.05^{\circ} \mathrm{C}$ in carp polyculture pond [18]. DoF (2008) recorded temperature ranges at $26-32.44^{\circ} \mathrm{C}$ in pond water, these were also more or less similar vary from the present study [19].

\section{Water $\mathrm{pH}$ value}

The observed value of $\mathrm{pH}(7.10 \pm 0.06$ to7.43 \pm 0.03$)$ recorded in present study. The minimum value was recorded with the treatment $\mathrm{WH} o\left(\mathrm{~T}_{1}\right)$ whereas the maximum value was recorded with the treatment $\mathrm{WH} 15\left(\mathrm{~T}_{2}\right)$. No significant differences $(\mathrm{P}<0.05)$ were found among the treatments for the mean values of water $\mathrm{pH}$ values. This statement also agreed with Shaha et al., (2003) who found the $\mathrm{pH}$ range varied from 7.43 to 8.05 in tilapia culture pond [20]. DoF (2008) recorded suitable $\mathrm{pH}$ ranges 5.66-7.44 in pond water [19]. These findings were more or less similar vary from the present study.

\section{Dissolved oxygen (DO) (mg/l)}

During the study period the highest Dissolved Oxygen $(5.57 \pm 0.03 \mathrm{mg} / \mathrm{l})$ was recorded with the treatment $\mathrm{WH} O\left(\mathrm{~T}_{1}\right)$ at $12^{\text {th }}$ week and the lowest value $(5.10 \pm 0.06 \mathrm{mg} / \mathrm{l})$ was recorded with the treatment $\mathrm{WH} 15\left(\mathrm{~T}_{2}\right)$ at $4^{\text {th }}$ week. No significant differences $(\mathrm{P}<0.05)$ were found among the treatments for

Table 2: Mean variation in the water quality parameters under different treatments.

\begin{tabular}{|c|c|c|c|}
\hline & WH O & WH 15 & WH 25 \\
\hline Water temperature $\left({ }^{\circ} \mathrm{C}\right)$ & $26.9 \pm 0.2^{\mathrm{a}}$ & $27.2 \pm 0.1^{\mathrm{a}}$ & $27.3 \pm 0.1^{\mathrm{a}}$ \\
\hline $\mathrm{pH}$ & $7.3 \pm 0.0^{\mathrm{a}}$ & $7.3 \pm 0.0^{\mathrm{a}}$ & $7.3 \pm 0.0^{\mathrm{a}}$ \\
\hline $\mathrm{DO}(\mathrm{mg} / \mathrm{l})$ & $5.38 \pm .02^{\mathrm{a}}$ & $5.3 \pm 0.0^{\mathrm{a}}$ & $5.4 \pm 0.0^{\mathrm{a}}$ \\
\hline Free $\mathrm{CO}_{2}(\mathrm{mg} / \mathrm{l})$ & $3.2 \pm 0.0^{\mathrm{a}}$ & $3.3 \pm 0.0^{\mathrm{a}}$ & $3.2 \pm 0.0^{\mathrm{a}}$ \\
\hline
\end{tabular}

Figure in a row bearing common letter $(s)$ do not differ significantly $(p<0.05)$.

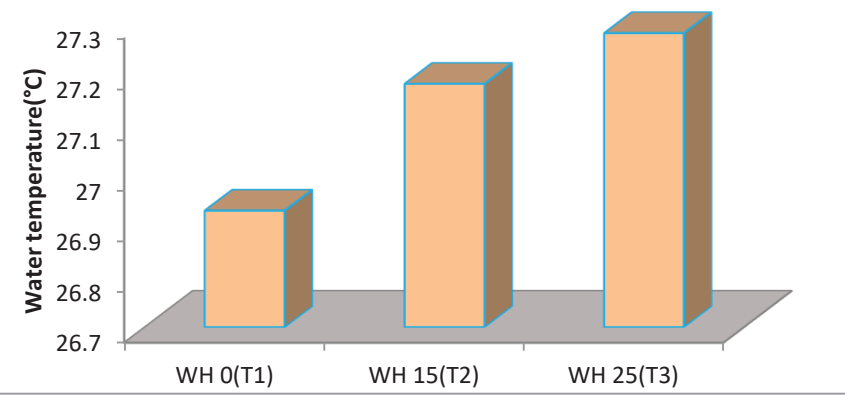

Figure 1: Mean variation in temperature under different treatments.

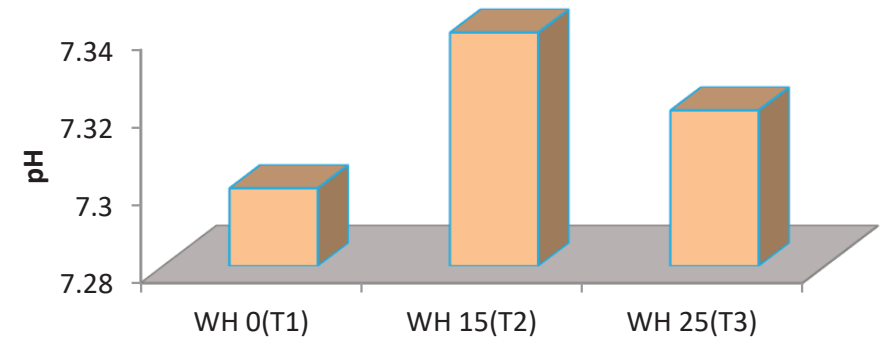

Figure 2: Mean variation in $\mathrm{pH}$ under different treatments.

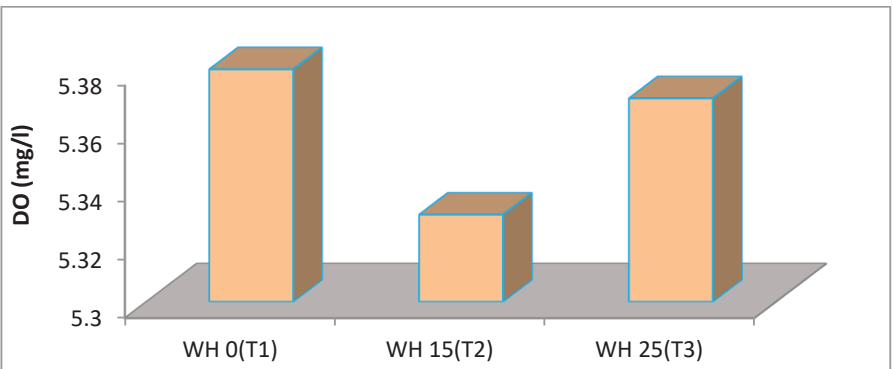

Figure 3: Mean variation in dissolved oxygen under different treatments.

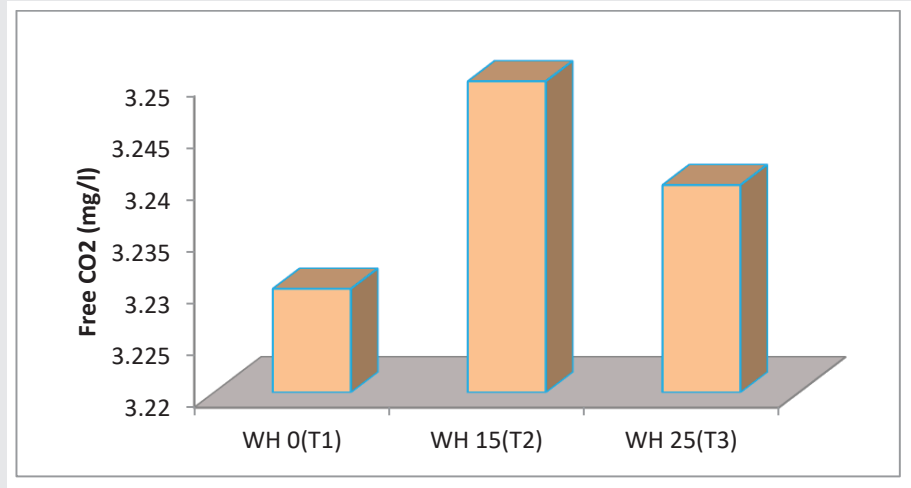

Figure 4: Mean variation in $\mathrm{CO} 2$ under different treatments.

the mean values of dissolved oxygen. DoF (2008) recorded a dissolved oxygen level of $1.19-7.74 \mathrm{mg} / 1$ should be from 2.2 to $7.1 \mathrm{mg} / 1$ in pond [19]. These statements were also more or less agreed with Hossain (2000), Uddin (2002), Chakraborty \& Mirza (2007) and Alim (2005) [20-24].

\section{Free CO2 (mg/l)}

The recorded mean values of Free $\mathrm{CO}_{2}$ were found to be ranged from $3.23 \pm 0.03$ to $3.25 \pm 0.03$. The minimum value was recorded with the treatment $\mathrm{WH} o\left(\mathrm{~T}_{1}\right)$ whereas the maximum value was recorded with the treatment $\mathrm{WH} 15\left(\mathrm{~T}_{2}\right)$. No significant differences $(\mathrm{P}<0.05)$ were found among the treatments for the mean values of Free $\mathrm{CO}_{2}(\mathrm{mg} / \mathrm{l})$. According to Ekubo and Abowei (2011) tropical fishes can tolerate $\mathrm{CO}_{2}$ levels over $100 \mathrm{mg} \mathrm{L}^{-1}$ but the ideal level of $\mathrm{CO}_{2}$ in fish pond is less than $10 \mathrm{mg} / \mathrm{L}$ [25]. Bhatnagar and Singh (2010) suggested, 5-8 ppm is essential for photosynthetic activity; $12-15 \mathrm{ppm}$ is sub lethal to fishes and 50-60 ppm is lethal to fishes [26]. From the above findings, it is concluded that the Free $\mathrm{CO}_{2}$ content of the experimental water body was within the good productive range.

\section{Fish growth performance (Mean Variation)}

The growth and production performance of roho labeo after the rearing period fed with water hyacinths meal (0\%-25\%) in terms of weight gain, SGR, FCR, and total production are presented in Table 3. In this study 0-25\% incorporation level of water hyacinths meal to produce cost effective formulated feed had no adverse effect on growth of the roho labeo. There was no significant difference between the growths of roho labeo fed diets containing $0 \%$ and $15 \%$ water hyacinth meal based diets. But a decreasing growth was found in fish group fed $25 \%$ water 
Table 3: Variation in the mean values of growth performance of roho labeo under different treatment during the study period.

\begin{tabular}{|c|c|c|c|}
\hline & WH 0 & WH 15 & WH 25 \\
\hline IW (g) & $199 \pm 17.9^{\mathrm{a}}$ & $200 \pm 9.79^{\mathrm{a}}$ & $202 \pm 6.9^{\mathrm{a}}$ \\
\hline FW(g) & $505.1 \pm 8.7^{\mathrm{a}}$ & $506.1 \pm 9.7^{\mathrm{a}}$ & $449.1 \pm 6.8^{\mathrm{b}}$ \\
\hline WG (g) & $305.6 \pm 1.9^{\mathrm{a}}$ & $306.1 \pm 3.6^{\mathrm{a}}$ & $247.07 \pm 2.6^{\mathrm{b}}$ \\
\hline FCR & $3.0 \pm 0.0^{\mathrm{b}}$ & $3.0 \pm 0.03^{\mathrm{b}}$ & $3.5 \pm 0.0^{\mathrm{a}}$ \\
\hline SGR (\%) & $1.1 \pm 0.0^{\mathrm{a}}$ & $1.11 \pm 0.01^{\mathrm{a}}$ & $0.95 \pm 0.0^{\mathrm{b}}$ \\
\hline TP & $40.4 \pm .2^{\mathrm{a}}$ & $40.49 \pm 0.2^{\mathrm{a}}$ & $35.93 \pm 0.1^{\mathrm{b}}$ \\
\hline
\end{tabular}

IW: Initial Weight; FW: Final Weight; WG: Weight Gain; FCR: Feed Conversion Ratio; SGR: Specific Growth Rate; TP: Total Production (kg/cage/cycle).

hyacinth meal based diets. There was no significant difference between the growth performance of fish that were fed diets containing up to $15 \%$ water hyacinth and fish that were fed the control diet [13]. Incorporation water hyacinths leaf meal up to $0-40 \%$ in the diets of roho labeo fingerlings showed on adverse effect on growth [12]. In the other study there was no significant difference $(\mathrm{P}<0.05)$ between the growths of fry fed diets containing $0 \%-20 \%$ water hyacinth meal [14].

\section{Initial weight}

Average initial weights of fish roho labeo under different treatments were $199 \pm 17.91,200 \pm 9.7 \mathrm{~g}$ and $202 \pm 6.9 \mathrm{~g}$ for $\mathrm{WH}$ $\mathrm{o}\left(\mathrm{T}_{1}\right), \mathrm{WH} 15\left(\mathrm{~T}_{2}\right)$ and $\mathrm{WH} 25\left(\mathrm{~T}_{3}\right)$ respectively. There were no significant differences in initial weight of fish in different treatments. This research was done with big size fingerling that is use in commercial fish farming. Other studies were done with roho labeo fingerlings average mean weight $4.0 \pm 0.14 \mathrm{~g}$ [12], common carp fry average mean weight 1.64g [13], Grass carp fry average mean weight $1.618 \pm 0.138 \mathrm{~g}$ [27]

\section{Final weight (g)}

The mean final weight $(\mathrm{g})$ of roho labeo was found to be varied in the ranges from $449.07 \pm 6.8 \mathrm{~g}$ to $506.09 \pm 9.7 \mathrm{~g}$. Among the different treatments, the lowest mean final weight was recorded with the treatment $\mathrm{WH} 25\left(\mathrm{~T}_{3}\right)$ whereas the highest mean final weight was recorded with the treatment WH $15\left(\mathrm{~T}_{2}\right)$. However, mean final weight gain was found $505.1 \pm 8.7 \mathrm{~g}$ in WHo (T1) fish group. Significant differences $(\mathrm{P}<0.05)$ were found among the treatment $\mathrm{WH} 25\left(\mathrm{~T}_{3}\right)$ and $\mathrm{WH} 15(\mathrm{~T} 2)$. This statement not agreed with Sadique et al.(2018) who found final weight well by using $\mathrm{WH} 40 \%(40.18 \pm 0.59 \mathrm{~g})$ than by using WHo\% (31.22 $\pm 0.24 \mathrm{~g})$ and WH10\% (32.53 $\pm 0.40 \mathrm{~g})$ [28]. There was no significant difference was found in final weight of fish groups fed $0 \%$ and $20 \%$ inoculation in diets of roho labeo fingerling [12].

\section{Mean weight gain (g)}

The mean weight gain $(\mathrm{g})$ of roho labeo was found to be varied in the ranges from $247.07 \pm 2.62 \mathrm{~g}$ to $306.10 \pm 3.57 \mathrm{~g}$. Among the different treatments, the lowest mean weight gain (g) was recorded with the treatment $\mathrm{WH} 25$ treatment group whereas the highest mean weight gain $(\mathrm{g})$ was recorded with the treatment WH15 fish group. There was no significant difference $(P<0.05)$ was found in fish groups fed $0 \%$ and $15 \%$
WH meal based diets. These results have the same opinion with the $0-15 \%$ inclusion of WH meal showed better growth performance in common carp fry [13]. There was no significant difference was found in fish groups fed $0 \%$ and $20 \%$ inoculation in diets of roho labeo fingerling with increasing level of raw WH leaf meal [12].

\section{Food conversion ratio (FCR)}

The mean food conversion ratio (FCR) of roho labeo was found to be varied in the ranges from $3.00 \pm 0.01$ to $3.50 \pm 0.04$. Among the different treatments, the lowest mean food conversion ratio (FCR) was recorded with the treatment $\mathrm{WH}$ $\left(\mathrm{T}_{1}\right)$ whereas the highest mean food conversion ratio (FCR) was recorded with the treatment $\mathrm{WH} 25\left(\mathrm{~T}_{3}\right)$. Significant differences $(P<0.05)$ were found among the treatment $\mathrm{WH}$ $25\left(\mathrm{~T}_{3}\right)$ The growth performance in terms of FCR showed a lower magnitude indicating an encouraging effect on economic involvement in fish farming. Mahmood et al. (2018) carried out an experiment and found FCR $(2.223 \pm 0.031)$ and $(2.188$ \pm 0.025 ) by using WH diet and control diet [27]. FCR value of $0 \%$ and $15 \%$ incorporation of water hyacinth meal respectively do not differ significantly in common carp [15]. It was found $2.35 \pm 0.06$ FCR by the inclusion of WH meal at the rate of $47 \%$ in the feed for Nile tilapia (Oreochromis niloticus) [29]. Also up to $30 \%$ inoculation of water hyacinth fed with cat fish (Clarias gariepinus) was not affected in FCR [30]. Also, FCR did not differ significantly among fish fed the various dietary treatments with $0-15 \% \mathrm{WH}$ meal [31]. In grass carp, FCR was $2.223 \pm$ 0.031 when fed with $15 \%$ WH based diet [27]

\section{Specific growth rate $(\%$, bwd- 1$)$}

The mean specific growth rate (\%, bwd-1) of roho labeo was found to be varied in the ranges from $0.95 \pm 0.01$ to $1.11 \pm 0.01$ after rearing in cage culture. Among the different treatments, the lowest mean specific growth rate (\%, bwd-1) was recorded with the treatment $\mathrm{WH} 25\left(\mathrm{~T}_{3}\right)$ whereas the highest mean specific growth rate $(\%$, bwd-1) was recorded with the treatment $\mathrm{WH} 15\left(\mathrm{~T}_{2}\right)$. Significant differences $(\mathrm{P}<0.05)$ were found among the treatment WH $25\left(\mathrm{~T}_{3}\right)$. Konyeme et al., (2006) found SGR $0.84 \%, 0.64 \%, 0.67 \%, 0.63 \%$ and $0.54 \%$ by using respectively $0 \%, 10 \%, 20 \%, 30 \%$ and $40 \%$ water hyacinth in fish feed ingredients as protein source fed with cat fish (Clarias gariepinus) [30]. Also $0-30 \%$ use of water hyacinth Meal was not affected in SGR with Red Tilapia [28] and with cat fish (Clarias gariepinus) [31]. In grass carp, SGR\% was $0.735 \pm 0.022$ when fed with $15 \%$ WH based diet [27].

\section{Total production}

The total productions $(\mathrm{kg} / \mathrm{cage} / \mathrm{cycle})$ of roho labeo with different treatments were found to be varied in the ranges from $35.93 \pm .07$ to $40.49 \pm .21(\mathrm{~kg})$. Significant differences $(\mathrm{P}<0.05)$ were found among the treatment $\mathrm{WH} 25\left(\mathrm{~T}_{3}\right)$ for the mean values of total production ( $\mathrm{kg} /$ cage/cycle) during the study period. Significantly highest $(\mathrm{P}<0.05)$ production was recorded at the treatment $\mathrm{WH} 15\left(\mathrm{~T}_{2}\right)$ whereas the lowest was recorded at the treatment $\mathrm{WH} 25\left(\mathrm{~T}_{3}\right)$. The results are in accord with the finding of many authors with the different fish 
species are used. This statement was similar with Sarker and Aziz (2017) who found total production nearly by using $\mathrm{WH}$ $0 \%(2,198.63 \pm 12)$ and WH $15 \%(2,075.36 \pm 11 \mathrm{~g})$ than WH $25 \%$ $(1,914 \pm 9.5 \mathrm{~g})$ in fish feed ingredients as protein source fed with Mirror Carp, (Cyprinus carpio var. specularis) [15]. Abdel-Fattah and Mamdouh (2008) has observed that at $20 \%$ of WH inclusion level in Tilapia feed, fish performance was reduced[32]. The efficient maximum digestion to nutrients is only up to $20 \%$ of water hyacinth inclusion in the diet of common carp [33] There is no significant difference between the growths of roho labeo fingerling fed diets containing $0 \%-40 \%$ water hyacinth meal based diets [33-36].

\section{Conclusion}

Incorporation of water hyacinth meal in fish feed as a feed ingredient that can be used to reduce the cost without affecting growth rate. This study demonstrated that the 15$25 \%$ incorporation level of water hyacinth meal supported the growth for roho labeo. Thus, $15 \%$ incorporation level of water hyacinth meal in formulated feed did not exert any adverse effect on growth performance of roho labeo. Moreover the unit production profit was high in fish group fed $15 \%$ water hyacinth meal based feed than fish group fed other feed. Further, such aquatic weed based feeds are cheaper as compared to the conventional feeds, supplementation of aquatic weeds in carp feed would also prove economically viable. Use of locally available feed ingredient like water hyacinth would reduce the cost of formulated feed and preparation of feed may be done at small scale level leading to employment generation in rural areas.

\section{Acknowledgement}

The authoress thankful to almighty Allah. The authoress also very grateful to Grant For Advanced Research In Education (GARE), Bangladesh Bureau of Educational Information and Statistics (BANBEIS), Ministry of Education for their research fund and supervision. The authoress are grateful to her juniors, Department of Fisheries, University of Rajshahi, for their support and cooperation.

\section{Author contributions}

Dr. Md. Al-Amin Sarker, Associate Professor, Department of Fisheries, University of Rajshahi, was the principle Investigator of this experiment. Mst. Kamrun Nahar conducted the experiment and analysis data. Mst. Hasna Banu and Mst. Turjaun Nesa investigated the experiment and wrote the manuscript.

\section{References}

1. DoF (2018) National Fish Week Compendium (In Bengali), Department of Fisheries, Ministry of Fisheries and Livestock, Bangladesh. 145-151.

2. Hardy RW (1995) Current issues in salmonid nutrition. Nutrition and Utilization Technology in Aquaculture, (ed.by Lim, C. and Sessa, D.J.), AOAC Press, Champaign, USA 26-35

3. Tacon AGJ, Dominy WG, Pruder GD (1998) Global trends and challenges in aqua feeds for marine shrimp. Aqua Feed International I4: 28-35.
4. Lim C, Klesius PH, Dominy W (1998) Soya bean products. International Aqua Feeds 3:17-23.

5. Hardy RW (1999) Alternate protein sources. Feed Manage 50: 25-28. Link: https://bit.ly/2zzWbxo

6. Storebakken T, Refstie S, Ruyter B (2000) Soy products as fat and protein sources in fish feeds for intensive aquaculture. Soy in Animal Nutrition (ed. by Drackley, J.K), Fed. Anim Sci Soc Savoy IL USA 127-170. Link: https://bit.ly/3erMZKq

7. Swick RA (2002) Soybean meal quality: assessing the characteristics of a major aquatic feed ingredient. Global Aquaculture Advocate 5: 46-49.

8. Kim S, Lee K (2009) Dietary protein requirement of juvenile tiger puffe (Takifugu rubripes). Aquaculture 287: 219-222. Link: https://bit.ly/3egjLOq

9. Sargent JR, Tocher DR, Bell JG (2002) The lipids. In J.E. Halver R.W. Hardy [eds.] Fish nutrition, $3^{\text {rd }}$ edition. Academic Press, San Diego, 181-257.

10. Edwards P, Kamal M, Wee KL (1985) Incorporation of composted and dried water hyacinth in pelleted feed for the tilapia Oreochromis niloticus (Peters). Aquaculture and Fisheries Management 1: 233-248. Link: https://bit.ly/36wUmgM

11. Ray AK, Das I (1994) Apparent digestibility of some aquatic macrophytes in rohu, Labeo rohita (Ham.), fingerlings. Journal of Aquaculture in the Tropics 9: $335-342$

12. Saha S, Ray AK (2011) Evaluation of Nutritive Value of Water Hyacinth (Eichhornia crassipes) Leaf Meal in Compound Diets for Rohu, Labeo rohita (Hamilton, 1822) Fingerlings after Fermentation with Two Bacterial Strains Isolated from Fish Gut. Turkish Journal of Fisheries and Aquatic Sciences 11 199-207. Link: https://bit.ly/2AbQh5C

13. Mohapatra SB, Patra AK (2013) Utilization of Water Hyacinth (Eichhornia crasipes) Meal as Partial Replacement for Fish meal on the Growth Performance of Cyprinus carpio fry. Int Res J Biological Sci 2: 85-89. Link: https://bit.ly/2M5hV6Z

14. Mohapatra SB, Patra AK (2015) Utilization of water hyacinth (Eichhornia crassipes) meal as partial fish protein Replacement in the diet of Cyprinus carpio fry. European Journal of Experimental Biology 5: 31-36. Link: https://bit.ly/2yAK7LJ

15. Sarker MA, Aziz I (2017) Incorporation of Water Hyacinth (Eichhornia crassipes) in Feed for Developing Eco-friendly Low Cost Feed of Mirror Carp Cyprinus carpio var.specularis (Linnaeus, 1758). Journal of Agroecology and Natural Resource Management 4: 5-9. Link: https://bit.ly/2zDhsGv

16. El-Sayed, Abdel-Fattah M (2003) Effects of fermentation methods on the nutritive value of water hyacinth for Nile tilapia Oreochromis niloticus (L.) fingerlings. Aquaculture 218: 471-478. Link: https://bit.ly/3gqFFAr

17. Jhingran VG (1997) Fish and Fisheries of India. 3rdedition. Hindustan Publishing Corporation, Delhi, India: 335-337

18. Bhuiyan MIA, Hossain MA, Ehsan MA, Hasan MR (2002) Effect of differen supplementary feeding methods on growth of fish in carp polyculyure. Depertment of Aquaculture, BAU. Bangladesh J Fish 25: 161-171.

19. DoF (2008) National Fish Week Compendium 2008, Department of Fisheries, Ministry of Fisheries and Livestock, Government of the People's Republic of Bangladesh.160.

20. Shaha DC, Devnath S, Roy NS, Dewan S (2003) Determination of suitable monoculture technique for GIFT in the northern region of Bangladesh. Bangladesh Journal of Fish 26: 67-72.

21. Hossain MY (2000) Effects of iso-phosphorus organic and inorganic fertilizers or water quality parameters and biological production. M. S. Dissertation. Department of Fisheries Management, Bangladesh Agricultural University, Mymensingh 24.

Citation: Sarker MA, Nahar K, Banu H, Nesa T (2020) Incorporation of Water Hyacinth, Eichhornia crassipes Meal in Aqua-feed and its Efficacy on Growth Performance of roho labeo, Labeo rohita (Hamilton, 1822) Reared in Cagev. Int J Aquac Fish Sci 6(2): 043-049. D0I: https://dx.doi.org/10.17352/2455-8400.000055 
22. Uddin MM (2002) Effects of addition of small fish on pond ecology and production in polyculture. M. S. thesis, Department of Fisheries Management, BAU, Mymensingh, Bangladesh 91-99.

23. Chakraborty BK, Mirza MJA (2007) Effect of stocking density on surviva and growth of endangered bata, Labeo bata (Hamilton-Buchanan) in nursery ponds. Aquaculture 265: 156-162. Link: https://bit.ly/2TJJy9U

24. Alim MA (2005) Developing a polyculture technique for farmers consumption and cash crop. Ph.D. Dissertation, Department of Fisheries Management Bangladesh Agricultural University, Mymensingh, Bangladesh 192

25. Ekubo AA, Abowei JFN (2011) Review of some water quality management principles in culture fisheries. Res J App Sci Eng Technol 3:1342-1357. Link: https://bit.ly/36B9lkw

26. Bhatnagar A, Singh G (2010) Culture fisheries in village ponds: A multilocation study in Haryana, India. Agric Biol J North Am 1: 961-968. Link: https://bit.ly/2XFFfOC

27. Mahmood S, Khan N, Iqbal KJ, Ashraf M, Khalique A (2018) Evaluation of water hyacinth (Eichhornia crassipes) supplemented feed on the growth, digestibility and histology of grass carp (Ctenopharyngodon idella) fingerlings, Journal of Applied Animal Research 46: 24-28. Link: https://bit.ly/3c7Lore

28. Sadique JK, Pandey A, Khairnar SO, Kumar NBT (2018) Effect of molassesfermented water hyacinth feed on growth and body composition of common carp, Cyprinus carpio. Journal of Entomology and zoology 6: 1161-1165. Link: https://bit.ly/3gCaDFU

29. Bag MP, Mahapatra SC, Rao PS, Chakrabarty D (2011) Making aquatic weed as potential feed for Nile tilapia (Oreochromis niloticus L.) and its impact on fatty acid profile. International Research of Pharmacy and Pharmacology 1 : 194-202. Link: https://bit.ly/36zspEV
30. Konyeme JE, Sogbesan AO, Ugwumba AAA (2006) Nutritive value and utilization of water hyacinth (Eichhornia crassipes) meal as plant protein supplement in the diet of Clarias gariepinus (Burchell, 1822) (Pisces: Clariidae) fingerlings .African Scientist, 7 : No. 3.

31. Hontiveros GJS, Tumbokon BLM, Serrano AE (2015) Protein concentrate of water hyacinth partially replaces soybean meal in the diet of the Nile tilapia Oreochromis niloticus juveniles. Animal Biology \& Animal Husbandry International Journal of the Bioflux Society. 7: 60-66. Link: https://bit.ly/36y6gHf

32. Al-Gburi EJM, Al-Shawi SA (2019) Effect of water hyacinth (Eichhornia crassipes) leaves meal substitution with maize on digestibility of common carp (Cyprinus carpio). Plant Archives 19: 19-21. Link: https://bit.ly/3gu1waf

33. Abdel-Fattah, ME, Mamdouh, K (2008) Optimum water temperature boosts the growth performance of Nile tilapia (Oreochromis niloticus) fry reared in a recycling system. Aquaculture Research 39: 670-672. Link: https://bit.ly/36zsatv

34. Konyeme, J.E., Sogbesan, A.O. and Ugwumba, A.A.A. 2006. Nutritive value and utilization of water hyacinth (Eichhornia crassipes) meal as plant protein supplement in the diet of Clarias gariepinus (Burchell, 1822) fingerlings. African Scientist 7: 31595-6881. Link: https://bit.ly/2B1EsiB

35. Soliman AK (1994) Water hyacinth proteins concentrate meal as a partial fish meal replacer in red tilapia diets. Animal and Fish Production Department, Faculty of Agriculture, University of Alexandria, Alexandria, Egypt.

36. Hossain MG (2004) Farming of Tilapia: Breeding plans, mass seed production and aquaculture techniques. Published by Habiba Akter Hussain, Mymensingh, Bangladesh 5-149.ecology and production in polyculture. M. S. thesis, Department of Fisheries Management, BAU, Mymensingh, Bangladesh 91-99.

\section{Discover a bigger Impact and Visibility of your article publication with}

\section{Peertechz Publications}

\section{Highlights}

* Signatory publisher of ORCID

* Signatory Publisher of DORA (San Francisco Declaration on Research Assessment)

* Articles archived in worlds' renowned service providers such as Portico, CNKI, AGRIS, TDNet, Base (Bielefeld University Library), CrossRef, Scilit, J-Gate etc.

* Journals indexed in ICMJE, SHERPA/ROMEO, Google Scholar etc.

* OAI-PMH (Open Archives Initiative Protocol for Metadata Harvesting)

* Dedicated Editorial Board for every journal

* Accurate and rapid peer-review process

* Increased citations of published articles through promotions

* Reduced timeline for article publication

Submit your articles and experience a new surge in publication services (https://www.peertechz.com/submission).

Peertechz journals wishes everlasting success in your every endeavours.

Copyright: @ 2020 Sarker MA, et al. This is an open-access article distributed under the terms of the Creative Commons Attribution License, which permits unrestricted use distribution, and reproduction in any medium, provided the original author and source are credited.

Citation: Sarker MA, Nahar K, Banu H, Nesa T (2020) Incorporation of Water Hyacinth, Eichhornia crassipes Meal in Aqua-feed and its Efficacy on Growth Performance of roho labeo, Labeo rohita (Hamilton, 1822) Reared in Cagev. Int J Aquac Fish Sci 6(2): 043-049. DOI: https://dx.doi.org/10.17352/2455-8400.000055 